\title{
Cognition in Elderly People: Study of the Short Form 8 (SF8) of the Wechsler-III Scale
}

\section{Cognição de Idosos: Estudo a partir da FA8 - Forma Abreviada da Wechsler-III}

\author{
Eliane Ferreira Carvalho Banhato ${ }^{*}, a, b$, Isabel Cristina Gonçalves Leite ${ }^{b}$, \\ Danielle Viveiros Guedes ${ }^{c}, \&$ Alfredo Chaoubah ${ }^{b}$ \\ ${ }^{a}$ Centro de Ensino Superior de Juiz de Fora, Juiz de Fora, Brasil \\ ${ }^{b}$ Universidade Federal de Juiz de Fora, Juiz de Fora, Brasil \\ $\&{ }^{c}$ Empresa Brasileira de Pesquisa Agropecuária, Sinop, Brasil
}

\begin{abstract}
Using psychometrical instruments adequate for the elderly cognitive evaluation is crucial. The Short Form (SF8) of the WAIS-III has been recommended for such purpose. This study aimed at characterizing cognition in the elderly using the SF8. A hundred ninety two individuals, aged 60 or older, were divided into case and control groups (G1 and G2). Women were the majority (75\%). The mean age was 75.9 years $(S D=9.1)$ and their educational level 6.40 years $(S D=4.8)$. There were significant differences in the groups' cognition according to the age, with better performance on verbal than executive skills. Schooling influenced the cognitive performance. The SF8 seemed to be advantageous in evaluating the elderly. It is important to investigate the behavior of individuals with different diagnoses in the SF8.

Keywords: Cognition, aging, Wechsler scale.

\section{Resumo}

Utilizar instrumentos psicométricos e adequados à avaliação cognitiva de idosos é fundamental. A Forma Abreviada (FA8) da WAIS-III vem sendo indicada nessa tarefa. Este estudo objetivou caracterizar a cognição de idosos, utilizando a FA8. Cento e noventa e dois indivíduos, de 60 ou mais anos, foram divididos em grupos caso e controle (G1 e G2). As mulheres foram maioria (75\%). A média etária foi de 75,9 anos $(D P=9,1)$ e a de escolaridade de 6,4 anos $(D P=4,8)$. Houve diferença significativa na cognição dos grupos segundo a faixa etária, com melhor rendimento em habilidades verbais que executivas. A escolaridade influenciou o desempenho cognitivo. A FA8 mostrou-se vantajosa na avaliação de idosos. Faz-se importante investigar o comportamento de indivíduos com diferentes diagnósticos na FA8.

Palavras-chave: Cognição, envelhecimento, escala Wechsler.
\end{abstract}

The last decades have witnessed an increase in the number of elderly people worldwide, with significant changes in the demographic profile. In the wake of this phenomenon, the epidemiologic transition has accounted for the substitution of chronic-degenerative diseases, more prevalent in the older population, for infectious diseases (Chaimowicz, 2007).

There have been international attempts, organized by scholars from several fields, to develop policies aimed at improving the quality of life of the elderly population. In Brazil, research on aging is relevant, not only because of the poor socioeconomic status of the elderly population (Berquó \& Leite, 1998), but also because of still unsolved problems in the areas of health, education, welfare and transport (Chaimowicz, 2007).

\footnotetext{
*Address: Departamento de Psicologia, Centro de Ensino Superior de Juiz de Fora, Rua Halfeld, 1179, Centro, Juiz de Fora, MG, Brasil 36016-000. E-mail: ebanhato@yahoo.com.br
}

As for mental health, it is known that intellectual decline may be due to several different aging trajectories. Although the age-related declines of attention, working memory, information processing speed and executive functions, for example, are physiological and do not interfere with the quality of life of the elderly (Stella, 2004), they may be related to more serious conditions, such as the dementias. A set of cognitive deficits characterizing an intermediate condition between health and disease, termed mild cognitive impairment (MCI), has also been acknowledged (Charchat-Fichman, Caramelli, Sameshima, \& Nitrini, 2005).

Although the dementias are known to increase with age, there are few population studies on this topic in Brazil. In addition, the results from these studies are heterogeneous, due to the different methods used for sample selection and testing.

Almeida-Filho, Santana and Pinho (1984) undertook the first population study on the prevalence of mental disorders in a low-income area of Salvador (BA), Brazil, reporting a $6.8 \%$ rate of organic brain disease in the 
population over 65 years of age. An investigation of mental impairment in a sample of 91 individuals from three subdistricts of São Paulo, conducted by Blay, Mari and Ramos (1989), showed a 5.5\% prevalence rate. Xavier (1999) reported a $19.7 \%$ rate of age-related cognitive decline in the city of Veranópolis (RS). In Catanduva (SP), Herrera, Caramelli, Silveira and Nitrini (2002) found prevalence rates of $1.6 \%$ among those aged $60-69$ years and up to $38.9 \%$ among those aged above 85 years. Lopes (2006) investigated the prevalence of dementia in a sample of 1.145 elders from Ribeirão Preto (SP). The screening phase identified $18.9 \%$ with cognitive and functional impairment, whereas the second phase, when a differential diagnosis was made, found a $6 \%$ rate of dementia.

MCI refers to a stage when impairment of a single cognitive function is detected, although within the physiological limits of normal aging. Notwithstanding, because $10-15 \%$ of those diagnosed with MCI go on to develop full-blown dementia, the clinical diagnosis of MCI merits careful follow-up (Stella, 2004). Lopes (2006) reported a $1.3 \%$ prevalence rate of $\mathrm{MCI}$ in a Brazilian elderly population.

When cognitive impairment is detected, the differential diagnosis is hampered by several factors: different possible aging trajectories, variability of the characteristics of the several age ranges that make up old age, and heterogeneity of the elders' access to education and work. Neuropsychological assessment may be useful in this context, as long as psychometrically reliable instruments are used (Alchieri \& Cruz, 2003).

Among the several tests available for cognitive investigation, the Wechsler Adult Intelligence Scale - Third Edition (WAIS-III; Wechsler, 1997) is considered the gold standard for intelligence assessment. It contains 14 subtests and assesses the general level of intellectual functioning, expressed as the total intelligence quotient (TIQ). The latter is subdivided into verbal (VIQ) and executive (EIQ) components (Wymer, Rayls, \& Wagner, 2003). Another measurement provided by the WAIS-III consists of the Factor Indexes (FIs): verbal comprehension (VC), perceptual organization (PO), working memory (WM) and processing speed (PS). Although these assess abilities which are similar to the VIQ and EIQ, they allow a more refined investigation of these capacities.

A limitation of the WAIS-III, however, is the amount of time which is necessary for its completion. Generally long in young adults (around 90 minutes), it can last much longer in elders, leading to fatigue, inattention, loss of motivation and loss of interest (Andraca, Cobo, Rivera, \& Pizarro, 1993).

The fact that the WAIS-III may be difficult to apply to the elderly population, in spite of being psychometrically adequate, has led to the use of its short forms (SFs), resulting from the partial use of the scale, that is, the use of some of its subtests. Among the several SFs proposed, that of Christensen, Girard and Bagby (2007), with a selection of eight subtests, showed high precision and validity on psychometric studies, besides a 50\% reduction of the application time. In Brazil, Coutinho (2009) investigated the psychometric potential of four SFs (with 2, 4, 7 and 8 subtests), concluding that SF8 was the best option, with valid and precise measurement of the FIs and IQs.

We thus aimed to characterize the cognitive performance of elders using the SF8. We also compared the results of those with and without cognitive impatiment, considering the differences of age ranges, sex and schooling.

\section{Method}

\section{Participants}

This was a cross-sectional study of a convenience sample composed of 192 individuals from both sexes, aged 60 years or above. In order to be included, the individual had to be an elderly and give an informed consent. Severe cognitive impairment and functional dependence were exclusion criteria.

The study was approved by the Ethics Committee of the Federal University of Juiz de Fora (MG), Brazil (document $n^{\circ}$ 205/2007). All participants signed an informed consent form.

\section{Instruments}

Sociodemographic Variables. We used a question-naire with questions on gender, age, marital status and schooling years.

Mini-Mental State Examination (MMSE; Folstein, Folstein, \& McHugh, 1975). It consists of 30 items which assess global cognition through a 30-point score.

SF8. With the following component subtests: (a) Vocabulary: Assessing the development of language and word recognition, with a maximum score of 66; (b) Arithmetic: With a maximum score of 22, this subtest assesses the ability to solve complex problems; (c) Similarities: Assessing the formation of verbal concept and abstract logical thinking, with a maximum score of 38 ; (d) Digit span: Investigating the working memory and the abilities of recalling and immediate repetition, with a total score of 30; (e) Picture completion: Assessing the ability to differentiate the essential from the details, that is, knowledge of the object, reasoning and long-term memory. The maximum score is 25; (f) Digit-span coding: Assessing the speed and accuracy of the eye/hand coordination and short-term visual memory. Total score is 133; (g) Matrix reasoning: Investigating visual information processing and abstract reasoning, with a total of 26 points; (h) Symbol search: Investigating attention and the speed of the cognitive process within a time-limit of 120 seconds. The total score is 60 .

\section{Procedures}

The study was conducted in a middle-sized city of Minas Gerais, southeastern Brazil. Fourteen percent of the 
population (approximately 500,000 inhabitants) was composed of elders (Instituto Brasileiro de Geografia e Estatística [IBGE], 2010). Participants were selected from the community and from geriatric homes.

The invited individuals were informed about the objectives and procedures of the study, and those who accepted to participate had an interview scheduled. The instruments were applied in the elders' place of residence, by previously trained psychology undergraduates and two of the authors (EFCB and DVG). It is noteworthy that the elders in whom any cognitive decline was detected were referred for neurological con-sultation.

The data were transferred to an electronic spreadsheet for descriptive and inferential analyses, with the adoption of a $95 \%$ confidence level. The MMSE was used for initial screening and sample division into those with or without cognitive impairment, according to the schooling-adjusted criteria proposed by Brucki, Nitrini, Caramelli, Bertolucci and Okamoto (2003).

It should be highlighted that for the correction of the WAIS-III the initial crude scores obtained in each subtest were converted into standardized weighted scores, through a system which uses a mean of 10 and a standard deviation of 3. This procedure allows comparison of the performance across the subtests. The results refer to the weighted scores for the reference groups (60-64 years and 65-89 years), obtained from the tables of the Application and Assessment Manual (Nascimento, 2004).
Statistical Analysis

We used the SPSS version 15.0 software (Statistical Package for Social Sciences) for the descriptions and statistical analyses. Pearson's correlation was used to verify association between the cognitive variables, namely MMSE and SF8. The Chi-squared test $\left(\chi^{2}\right)$ was used for analysis of the categorical variables. Comparison between the cognition final scores, according to the different schooling years, was made with variance analysis (ANOVA) and $t$ test for paired samples in the intra-group results, and $t$ test for independent groups for inter-group comparisons. Co-variance analysis (ANCOVA) was used to analyze the cognitive performance, controlling for schooling years.

\section{Results}

Of the 192 elders, $75 \%(n=144)$ were women $\left(\chi^{2}=\right.$ $48.00 ; p<.001)$. Their ages ranged from 60 to 98 years (mean 75.9, $S D=9.1$ ). When the age ranges were considered, the sample showed no difference in its composition $\left(\chi^{2}=4.16 ; p=.125\right)$.

There was a predominance of elders with 1-4 schooling years $\left(\chi^{2}=71.28 ; p<.001\right)$. As for the marital status, there was an expressive number of widowed elders $\left(\chi^{2}=\right.$ $60.37 ; p=.001)$. The sociodemographic description of the sample is shown in Table 1.

Table 1

Sociodemographic Results of the Total Sample and of the Groups

\begin{tabular}{lcccccc}
\hline Variables & \multicolumn{2}{c}{ Total Sample } & \multicolumn{2}{c}{$\begin{array}{c}\text { With Cognitive } \\
\text { Decline }\end{array}$} & \multicolumn{2}{c}{$\begin{array}{c}\text { Without Cognitve } \\
\text { Decline }\end{array}$} \\
\cline { 2 - 7 } & $n$ & $\%$ & $n$ & $\%$ & $n$ & $\%$ \\
\hline Gender & & & & & & \\
Male & 48 & 25.0 & 24 & 23.5 & 24 & 26.7 \\
Female & 144 & 75.0 & 78 & 76.5 & 66 & 73.3 \\
Age (years) & $M=75.87$ & $(S D=9.14)$ & $M=77.90$ & $(S D=9.31)$ & $M=73.57$ & $(S D=8.41)$ \\
60-69 & 55 & 28.6 & 22 & 21.6 & 33 & 36.7 \\
$70-79$ & 60 & 31.3 & 30 & 29.4 & 30 & 33.3 \\
$>$ 80 & 77 & 40.1 & 50 & 49.0 & 27 & 30.0 \\
Schooling & $M=6.40$ & $(S D=4.81)$ & $M=4.77$ & $(S D=4.05)$ & $M=8.24$ & $(S D=4.95)$ \\
Illiterate & 17 & 8.9 & 15 & 14.7 & 2 & 2.2 \\
1-4 years & 84 & 43.7 & 51 & 50.0 & 33 & 36.7 \\
5-8 years & 32 & 16.7 & 15 & 14.7 & 17 & 18.9 \\
9- 11 years & 29 & 15.1 & 12 & 11.8 & 17 & 18.9 \\
$>12$ years & 30 & 15.6 & 9 & 8.8 & 21 & 23.3 \\
Marital status & & & & & & \\
Widowed & 83 & 43.2 & 51 & 50.0 & 32 & 35.6 \\
Married & 64 & 33.3 & 25 & 24.5 & 39 & 43.3 \\
Divorced/Separated & 17 & 8.9 & 9 & 8.8 & 8 & 8.9 \\
Single & 27 & 14.1 & 17 & 16.7 & 10 & 11.2 \\
\hline
\end{tabular}

Note. Source: Study data.

${ }^{a}$ One participant declined to inform on the marital status. 
Banhato, E. F. C., Leite, I. C. G., Guedes, D. V. \& Chaoubah, A. (2012). Cognition in Elderly People: Study of the Short Form 8 (SF8) of the Wechsler-III Scale.

Global and SF8-assessed cognitive performances are described in Table 2. Pearson's correlation showed a strong and statistically significant association between
SF8 and MMSE $(r=.79 ; p<.001)$. There was also a positive and significant correlation between the number of schooling years and the tests of cognitive performance (MMSE: $r=.52 ; p<.001$ and SF8: $r=.67 ; p<.001$ ).

Table 2

Cognitive Performance of the Total Sample and of the Groups With (G1) and Without (G2) Cognitive Decline

\begin{tabular}{lcccc}
\hline Variables & $\begin{array}{c}\text { Total Sample } \\
\text { Mean }(S D)\end{array}$ & $\begin{array}{c}\text { G1 } \\
\text { Mean }(S D)\end{array}$ & $\begin{array}{c}\text { G2 } \\
\text { Mean }(S D)\end{array}$ & $t^{*}$ \\
\hline SF8 Total & $107.43(29.28)$ & $89.11(20.59)$ & $128.2(23.21)$ & -15.51 \\
V & $9.57(3.35)$ & $7.69(2.92)$ & $11.71(2.38)$ & -12.21 \\
S & $10.76(2.92)$ & $9.13(2.47)$ & $12.61(2.21)$ & -12.29 \\
A & $8.92(3.01)$ & $7.34(2.32)$ & $10.71(2.73)$ & -11.18 \\
D & $10.90(3.73)$ & $9.01(2.93)$ & $13.03(3.38)$ & -9.34 \\
VIQ & $60.23(13.72)$ & $49.75(12.74)$ & $72.10(12.55)$ & -14.56 \\
PC & $10.03(3.59)$ & $8.05(2.42)$ & $12.28(3.37)$ & -12.06 \\
MR & $9.58(3.00)$ & $8.20(2.16)$ & $11.16(3.05)$ & -10.06 \\
DC & $8.65(2.81)$ & $7.32(2.11)$ & $10.16(2.76)$ & -9.92 \\
SS & $9.54(2.79)$ & $8.08(1.97)$ & $11.20(2.67)$ & -11.39 \\
EIQ & $47.20(13.72)$ & $39.36(9.29)$ & $56.09(12.47)$ & -13.62 \\
\hline
\end{tabular}

Note. Source: Study data. Key: V = Vocabulary; $\mathrm{S}=$ Similarities; $\mathrm{A}=$ Arithmetic; $\mathrm{D}=$ Digit span; VIQ = Verbal IQ; $\mathrm{PC}=$ Picture completion; $\mathrm{MR}=$ Matrix reasoning; $\mathrm{DC}=$ Digit-span coding; $\mathrm{SS}=$ Symbol search; EIQ = Executive IQ .

* All the differences were statistically significant $(p<.001)$.

Because schooling interferes with the MMSE results, Brucki et al. (2003) suggested that this variable should be taken into account when the instrument was used. Our sample was thus separated into two groups: G1, the group with cognitive impairment, composed of those who had an average or below-average score, and G2, the group with preserved cognition, composed of those who scored above average. The sociodemographic and cognitive profiles of the groups were analyzed separately and are described below.

\section{Group 1 (G1)}

Composed of 102 elders ( $53.10 \%$ of the sample), there was a predominance of individuals aged 80 years or above (older elderly), $\left(\chi^{2}=12.23 ; p<.01\right)$. The number of women was significantly higher $\left(\chi^{2}=28.59 ; p<.001\right)$. As for education, most had only 1-4 schooling years $\left(\chi^{2}\right.$ $=58.59 ; p<.001)$. It is noteworthy that $88.2 \%(n=15)$ of all illiterate subjects of the sample belonged to this group. As for the marital status, widowed individuals significantly predominated $\left(\chi^{2}=39.02 ; p<.001\right)$. The distribution of the frequencies of the sociodemographic variables of this group can be seen in Table 1 .

MMSE-assessed global cognitive performance had a mean of 20.0 points $(S D=5.27)$, with a range from 3 to 27 points. The SF8 and IQs-assessed specific cognitive performances are shown in Table 2. The mean for verbal domain tasks was significantly higher than that for the executive tasks in this group $(t=12.26 ; p<.001)$.

Investigation of the cognitive performance assessed with the SF8 factor indexes showed means of 25.22 (SD $=7.54$ ) for the Verbal Comprehension Index (VCI), 24.37 $(S D=6.10)$ for the Perceptual Organization Index (POI), $24.53(S D=6.69)$ for the Working Memory Index (WMI), and $15.40(S D=3.85)$ for the Processing Speed Index (PSI).

When this group's cognitive performance was observed according to gender, there was no significant difference, except for the Arithmetic $(t=2.12 ; p<.05)$ and Digit $\operatorname{span}(t=2.00 ; p<.05)$ subtests. In both cases men had higher performances, with means of $8.21(S D=2.21)$ and $10.04(S D=3.14)$, respectively. Among the women, the means of these subtests were $7.08(S D=2.31)$ and 8.69 $(S D=2.80)$, respectively. Men also performed higher in the WMI, with a mean of $27.38(S D=7.31)$ against 23.65 $(S D=6.28)$ for women $(t=2.44 ; p<.05)$.

Age range was not significantly associated with the MMSE-assessed global cognitive performance $(F=$ $2.14 ; p=.12)$. The same was observed for the total SF8 (Table 3).

The association between schooling and the cognitive performance assessed with the SF8, its IQs and Factor Indexes was established with ANOVAS and proved to be significant $(p<.01)$. Table 4 describes these results. 
Psicologia: Reflexão e Crítica, 25(1), 96-104.

Table 3

Cognitive Performance of Group 1 According to Age Range

\begin{tabular}{|c|c|c|c|c|c|}
\hline \multirow[b]{2}{*}{ Variables } & \multicolumn{3}{|c|}{ Age Range (years) } & \multirow[b]{2}{*}{$F$} & \multirow[b]{2}{*}{$p$-value } \\
\hline & $\begin{array}{c}60-69 \\
\text { Mean }(S D)\end{array}$ & $\begin{array}{l}\text { 70-79 } \\
\text { Mean }(S D)\end{array}$ & $\begin{array}{c}>80 \\
\text { Mean }(S D)\end{array}$ & & \\
\hline SF8 Total & $88.22(22.32)$ & $88.79(22.20)$ & 89.69 (19.19) & 0.04 & .958 \\
\hline V & $7.77(2.74)$ & $7.27(2.91)$ & $7.90(3.04)$ & 0.45 & .641 \\
\hline $\mathrm{S}$ & $8.68(2.46)$ & $8.73(2.43)$ & $9.56(2.48)$ & 1.52 & .224 \\
\hline A & $7.41(2.63)$ & $7.70(2.12)$ & $7.10(2.31)$ & 0.63 & .534 \\
\hline $\mathrm{D}$ & $9.05(3.23)$ & $8.70(2.84)$ & $9.18(2.88)$ & 0.25 & .779 \\
\hline VIQ & $49.36(12.90)$ & $48.60(12.32)$ & $50.61(13.10)$ & 0.24 & .785 \\
\hline $\mathrm{PC}$ & $8.18(2.48)$ & $8.43(3.23)$ & $7.76(1.76)$ & 0.76 & .469 \\
\hline MR & $8.00(2.22)$ & $8.20(2.16)$ & $8.28(2.18)$ & 0.13 & .882 \\
\hline $\mathrm{DC}$ & $7.09(2.63)$ & $7.43(2.22)$ & $7.09(2.63)$ & 0.18 & .837 \\
\hline SS & $7.41(2.08)$ & $8.06(1.85)$ & $7.41(2.08)$ & 1.88 & .158 \\
\hline EIQ & $38.86(10.41)$ & 40.19 (10.94) & $39.08(7.76)$ & 0.17 & .843 \\
\hline VCI & $24.68(7.30)$ & $24.00(7.27)$ & $26.19(7.80)$ & 0.86 & .426 \\
\hline POI & $24.27(6.52)$ & $24.95(7.25)$ & $24.06(5.20)$ & 0.20 & .819 \\
\hline WMI & $24.68(7.30)$ & $24.60(6.73)$ & $24.42(6.52)$ & 0.01 & .986 \\
\hline PSI & $14.50(4.57)$ & $15.50(3.74)$ & $15.74(3.59)$ & 0.80 & .452 \\
\hline
\end{tabular}

Note. Source: Study data. Key: V = Vocabulary; S = Similarities; A = Arithmetic; D = Digit span; VIQ = Verbal IQ; PC = Picture completion; $\mathrm{MR}=$ Matrix reasoning; $\mathrm{DC}=$ Digital-span coding; $\mathrm{SS}=$ Symbol search; EIQ = Executive IQ; VCI = Verbal comprehension index; POI $=$ Perceptual organization index; WMI $=$ Working memory index; PSI $=$ Processing speed index .

Table 4

Cognitive Performance of Group 1 According to Schooling

\begin{tabular}{|c|c|c|c|c|c|c|c|}
\hline \multirow[b]{2}{*}{ Variables } & \multicolumn{5}{|c|}{ Schooling } & \multirow[b]{2}{*}{$F$} & \multirow[b]{2}{*}{$p$-value } \\
\hline & $\begin{array}{l}\text { Illiterate } \\
\qquad M(S D)\end{array}$ & $\begin{array}{c}1-4 \text { years } \\
M(S D)\end{array}$ & $\begin{array}{c}5-8 \text { years } \\
M(S D)\end{array}$ & $\begin{array}{c}\text { 9-11 years } \\
M(S D)\end{array}$ & $\begin{array}{r}>12 \text { years } \\
M(S D)\end{array}$ & & \\
\hline SF8 Total & $68.80(12.89)$ & $83.97(14.00)$ & $100.31(20.18)$ & $112.15(24.94)$ & $102.70(9.39)$ & 16.67 & .001 \\
\hline $\mathrm{V}$ & $4.93(1.53)$ & $6.90(2.14)$ & $9.07(3.10)$ & $10.67(3.02)$ & $10.44(1.42)$ & 16.41 & .001 \\
\hline $\mathrm{S}$ & $7.53(1.30)$ & $8.31(1.82)$ & $10.07(2.84)$ & $11.58(2.91)$ & $11.56(1.24)$ & 12.51 & .001 \\
\hline A & $5.93(2.40)$ & $7.06(1.78)$ & $8.80(2.83)$ & $8.25(3.04)$ & $7.67(1.41)$ & 3.96 & .005 \\
\hline $\mathrm{D}$ & $5.87(2.72)$ & 8.67 (1.98) & $10.73(2.96)$ & $11.33(2.23)$ & $10.22(3.73)$ & 11.41 & .001 \\
\hline VIQ & $36.40(9.10)$ & $46.41(8.18)$ & $58.00(8.18)$ & $62.75(13.52)$ & $59.83(7.81)$ & 19.02 & .001 \\
\hline $\mathrm{PC}$ & $6.67(1.11)$ & $7.45(1.76)$ & $8.93(3.15)$ & $11.00(3.01)$ & $8.33(1.50)$ & 9.26 & .001 \\
\hline MR & 6.33 (1.59) & $8.06(1.86)$ & $8.80(1.93)$ & $9.67(3.05)$ & $9.11(1.45)$ & 5.87 & .001 \\
\hline $\mathrm{DC}$ & $6.40(1.92)$ & $6.98(1.68)$ & $7.60(2.23)$ & $8.92(3.15)$ & $8.22(1.64)$ & 3.56 & .009 \\
\hline SS & $7.33(2.06)$ & 7.57 (1.60) & $8.33(1.91)$ & $10.00(2.52)$ & $9.22(0.83)$ & 6.06 & .001 \\
\hline EIQ & $32.40(4.84)$ & $37.56(7.17)$ & $42.31(9.69)$ & $49.40(13.25)$ & $42.86(5.47)$ & 8.90 & .001 \\
\hline VCI & $18.70(3.67)$ & $22.82(5.37)$ & $28.70(7.99)$ & $33.38(7.91)$ & $33.00(2.90)$ & 18.14 & .001 \\
\hline POI & $19.50(2.66)$ & $23.26(4.81)$ & $26.60(6.74)$ & $31.00(8.12)$ & $26.17(3.28)$ & 9.40 & .001 \\
\hline WMI & $17.70(6.66)$ & $23.59(4.59)$ & $29.30(7.05)$ & $29.38(6.18)$ & $26.83(6.20)$ & 11.07 & .001 \\
\hline PSI & $13.73(3.77)$ & $14.55(3.09)$ & $15.93(3.77)$ & $18.92(5.43)$ & $17.44(1.94)$ & 5.29 & .001 \\
\hline
\end{tabular}

Note. Source: Study data. Key: V = Vocabulary; S = Similarities; A = Arithmetic; D = Digit span; VIQ = Verbal IQ; PC = Picture completion; $\mathrm{MR}=$ Matrix reasoning; $\mathrm{DC}=$ Digital-span coding; SS = Symbol search; EIQ = Executive IQ; VCI = Verbal comprehension index; POI = Perceptual organization index; WMI = Working memory index; PSI $=$ Processing speed index.

\section{Group 2 (G2)}

This group was composed of 90 elders $(46.9 \%$ of the total sample) and had a homogeneous distribution of the age ranges, without any significant difference between them $\left(\chi^{2}=.60 ; p=.741\right)$. Women significantly predominated $\left(\chi^{2}=19.60 ; p<.001\right)$, as shown in Table 1 . 
Banhato, E. F. C., Leite, I. C. G., Guedes, D. V. \& Chaoubah, A. (2012). Cognition in Elderly People: Study of the Short Form 8 (SF8) of the Wechsler-III Scale.

As for schooling, there was a significant difference among the individuals of group $2\left(\chi^{2}=27.33 ; p<.001\right)$ (Table 1). As for the marital status, there was an expressive participation of married and widowed individuals $\left(\chi^{2}=\right.$ $32.75, p<.001)$. The detailed sociodemographic profile of group 2 is shown in Table 1.

The MMSE-assessed global cognitive profile of this group showed a mean of 27.93 points $(S D=1.53)$, with $68.90 \%$ of the participants scoring 28 points or above. Twelve participants $(13.3 \%)$ scored the maximum of 30 points.

As for the SF8, the group had higher means in the verbal subtests $(t=16.19 ; p<.001)$. The means of the Factor Indexes were $36.46(S D=6.16)$ for Verbal Comprehension; $35.15(S D=8.32)$ for Perceptual Organization; 35.62
$(S D=8.00)$ for Working Memory and; $21.36(S D=5.07)$ for Processing Speed. The performances in the SF8 subtests are shown in Table 2.

Assessment of the cognitive performance according to gender did not show any significant difference in the SF8 measurements, except for the Arithmetic subtest, in which men $(M=12.13 ; S D=2.47)$ performed higher than women $(M=10.20 ; S D=2.65[t=3.10 ; p<.01])$.

When SF8-assessed performance was examined according to age range, there was a negative association with Executive IQ, Processing Speed Index and the Arithmetic and Digit-span coding subtests, as shown in Table 5. The multiple Bonferroni comparisons indicated that the differences between the performance means were significant at the 60-69 years and 80 years or above age ranges $(p<.01)$.

Table 5

Cognitive Performance of Group 2 According to Age Range

\begin{tabular}{lccccc}
\hline & \multicolumn{3}{c}{ Age Range (years) } & & \\
\cline { 2 - 4 } Variables & $60-69$ & $70-79$ & & \\
& Mean $(S D)$ & Mean $(S D)$ & Mean $(S D)$ & & $p$-value \\
\hline SF8 Total & $132.86(25.62)$ & $129.95(22.63)$ & $120.53(19.29)$ & 2.29 & .107 \\
V & $11.15(2.41)$ & $11.80(2.40)$ & $12.30(2.23)$ & 1.79 & .174 \\
S & $12.58(2.24)$ & $12.77(2.31)$ & $12.48(2.12)$ & 0.12 & .885 \\
A & $11.70(2.95)$ & $10.63(2.62)$ & $9.59(2.13)$ & 4.82 & $.010^{*}$ \\
D & $13.27(3.34)$ & $13.43(3.49)$ & $12.30(3.30)$ & 0.93 & .396 \\
VIQ & $73.04(13.25)$ & $72.95(12.85)$ & $70.00(11.51)$ & 0.53 & .588 \\
PC & $12.88(3.42)$ & $12.80(3.35)$ & $10.96(3.09)$ & 3.06 & .052 \\
MR & $11.73(3.39)$ & $11.23(3.20)$ & $10.37(2.27)$ & 1.50 & .229 \\
DC & $11.21(3.31)$ & $10.10(2.17)$ & $8.93(2.07)$ & 5.64 & $.005^{*}$ \\
SS & $11.76(3.28)$ & $11.37(2.23)$ & $10.33(2.11)$ & 2.26 & .111 \\
EIQ & $59.82(13.96)$ & $57.00(11.71)$ & $50.53(9.46)$ & 4.57 & $.013^{*}$ \\
VCI & $35.59(6.32)$ & $36.85(6.37)$ & $37.17(5.80)$ & 0.56 & .573 \\
POI & $36.91(9.11)$ & $36.05(8.39)$ & $32.00(6.42)$ & 2.97 & .056 \\
WMI & $37.45(8.21)$ & $36.10(7.94)$ & $32.83(7.30)$ & 2.65 & .076 \\
PSI & $22.97(6.25)$ & $21.47(3.92)$ & $19.26(3.87)$ & 4.28 & $.017^{*}$ \\
\hline
\end{tabular}

Note. Source: Study data. Key: V = Vocabulary; $\mathrm{S}=$ Similarities; A = Arithmetic; $\mathrm{D}=$ Digit span; VIQ = Verbal IQ; PC = Picture completion; $\mathrm{MR}=$ Matrix reasoning; $\mathrm{DC}=$ Digital-span coding; SS = Symbol search; EIQ = Executive IQ; VCI = Verbal comprehension index; POI $=$ Perceptual organization index; WMI $=$ Working memory index; PSI $=$ Processing speed index .

Comparison of the cognitive performance and the schooling of group 2 participants showed that the differences obtained are unlikely to have originated from a sampling error alone $(p<.01)$, in all measurements performed. We can thus infer that the more schooling years, the higher the cognitive performance (Table 6).

\section{Comparison between G1 and G2 Groups (with and without cognitive impairment)}

When considering the sociodemographic variables, as described in Table 1, comparison of the age means of the two groups showed a significant difference ( $t=3.37 ; p<$ $.001)$, G1 being composed by older individuals. The same happened with the number of schooling years, with more educated elders in $\mathrm{G} 2(t=-5.34 ; p<.001)$. As for gender distribution, there was no significant difference $\left(\chi^{2}=0.25 ; p=.616\right)$. Concerning cognitive performance, SF8 means were significantly lower among group 1 individuals $(p<.001)$. Table 2 describes these results.

Once G1 was composed of individuals with fewer schooling years, we chose to perform a covariance analysis (ANCOVA), controlling for the total number of schooling years. The relationship between schooling and 
Psicologia: Reflexão e Crítica, 25(1), 96-104.

Table 6

Cognitive Performance of Group 2 According to Schooling

\begin{tabular}{|c|c|c|c|c|c|c|c|}
\hline \multirow[b]{2}{*}{ Variables * } & \multicolumn{5}{|c|}{ Schooling } & \multirow[b]{2}{*}{$F$} & \multirow[b]{2}{*}{$p$-value } \\
\hline & $\begin{array}{l}\text { Illiterate } \\
M(S D)\end{array}$ & $\begin{array}{l}1-4 \text { years } \\
M(S D)\end{array}$ & $\begin{array}{l}\text { 5-8 years } \\
M(S D)\end{array}$ & $\begin{array}{l}\text { 9-11 years } \\
M(S D)\end{array}$ & $\begin{array}{l}>12 \text { years } \\
M(S D)\end{array}$ & & \\
\hline SF8 Total & $80.15(.60)$ & $118.37(19.71)$ & $120.86(14.89)$ & 138.03 (17.90) & $146.18(22.00)$ & 11.84 & .000 \\
\hline $\mathrm{V}$ & $7.50(.71)$ & $10.88(2.29)$ & $11.47(2.03)$ & $12.94(1.71)$ & $12.62(2.44)$ & 5.43 & .001 \\
\hline S & $7.50(.71)$ & $11.55(1.90)$ & $12.29(1.86)$ & $13.76(1.98)$ & $14.10(1.37)$ & 12.47 & .000 \\
\hline A & $6.00(1.41)$ & $9.67(1.99)$ & $10.18(1.91)$ & $11.53(3.04)$ & $12.57(2.80)$ & 7.29 & .000 \\
\hline $\mathrm{D}$ & $8.50(2.12)$ & $12.55(3.26)$ & $11.53(2.87)$ & $14.29(3.06)$ & $14.43(3.41)$ & 3.84 & .006 \\
\hline VIQ & $44.25(5.30)$ & $66.95(10.78)$ & $68.20(7.63)$ & 78.79 (9.44) & $80.57(12.19)$ & 11.60 & .000 \\
\hline $\mathrm{PC}$ & $7.50(2.12)$ & $11.24(3.30)$ & 11.47 (2.67) & $13.59(3.61)$ & $13.95(2.82)$ & 4.59 & .002 \\
\hline MR & $7.50(2.12)$ & $10.64(3.22)$ & $10.53(2.03)$ & $10.88(2.29)$ & $13.05(3.34)$ & 3.56 & .010 \\
\hline DC & $6.50(.71)$ & $8.91(1.84)$ & $9.53(2.37)$ & $11.00(2.34)$ & $12.29(3.15)$ & 8.40 & .000 \\
\hline SS & $7.50(.71)$ & $9.73(1.94)$ & $10.76(1.68)$ & $12.70(2.26)$ & $13.00(3.00)$ & 10.37 & .000 \\
\hline EIQ & $35.90(5.90)$ & 51.41(11.73) & $52.65(8.99)$ & $59.23(10.48)$ & $65.61(11.31)$ & 8.05 & .000 \\
\hline VCI & $22.50(.00)$ & $33.64(5.64)$ & 35.65 (4.93) & $40.06(4.43)$ & $40.07(4.98)$ & 11.10 & .000 \\
\hline POI & $22.50(6.36)$ & $32.82(8.50)$ & $33.00(5.61)$ & $36.71(7.56)$ & $40.50(7.65)$ & 5.25 & .001 \\
\hline WMI & $21.75(5.30)$ & $33.32(6.71)$ & $32.56(4.68)$ & $38.74(7.74)$ & $40.50(8.77)$ & 6.81 & .000 \\
\hline PSI & $14.00(.00)$ & 18.64 (3.36) & 20.29 (3.84) & $23.71(4.24)$ & $25.29(5.54)$ & 11.19 & .000 \\
\hline
\end{tabular}

Note. Source: Study data. Key: V = Vocabulary; S = Similarities; A = Arithmetic; D = Digit span; VIQ = Verbal IQ; PC = Picture completion; $\mathrm{MR}=$ Matrix reasoning; $\mathrm{DC}=$ Digital-span coding; SS = Symbol search; EIQ = Executive IQ; VCI = Verbal comprehension index; POI = Perceptual organization index; WMI = Working memory index; PSI $=$ Processing speed index.

* Differences were statistically significant $(p<.01)$.

FA8-assessed cognitive performance is unlikely to be due to sampling error if the null hypothesis is true $[F(1.189)$ $=120.83 ; p<.001]$. Once the schooling effects were removed, the groups differed as for their cognitive performances $[F(1,189)=115,61 ; p<.001]$.

\section{Discussion}

The characteristics of our population are similar to those of other Brazilian studies, which show a larger number of female elders, which characterizes the feminization of aging (Chaimowicz, 2007; Neri, 2008). This phenomenon is due to several factors, such as: (a) higher relative number of women in the elderly population, (b) higher female longevity and, (c) relative increase of the number of women who are economically active and household heads (Neri, 2008).

As for schooling, the means we found - both for those with cognitive decline and for those without - were higher than the national average of 3.4 years (IBGE, 2002), which may be due to a cohort effect. On the other hand, the significant difference in intergroup schooling, with higher levels among those cognitively intact (G2), pointed to a strong influence of this variable on human cognition. According to the literature schooling is protective of normal or healthy aging (Argimon \& Stein, 2005; Brucki et al., 2003).
Because access to school is heterogeneous in Brazil, with a significant number of drop-outs, this factor must be taken into account in the implementation of educational programs, including those targeting the elderly population. More and better access to continuing education may lend better quality of life to aging (Cachioni, 2007).

Although the total sample had a majority of widowed elders, group separation showed an interesting finding: G1 had a significant majority of widowed elders, whereas G2 had a predominance of married elders. This may indicate an important supportive role of the spouse, with a positive influence on the cognitive health of the partner (Erbolato, 2002).

The strong association between the cognitive tests (MMSE and SF8) indicates that both assess the same construct (cognition). FA8-assessed cognition was above average in G2, a superior result according to the classical correction of the scale. This finding underscores the possibility of cognition preservation during aging (Argimon \& Stein, 2005; Charchat-Fichman et al., 2005).

On the other hand, the SF8-assessed performance of G1 members was characterized by an inferior mean, indicating cognitive impairment. However, it is not possible to state that these scores diagnose dementia, as this condition requires complementary instruments, such as assessments of the functional capacity and depressive symptoms, to be diagnosed (Nitrini et al., 2005). 
Banhato, E. F. C., Leite, I. C. G., Guedes, D. V. \& Chaoubah, A. (2012). Cognition in Elderly People: Study of the Short Form 8 (SF8) of the Wechsler-III Scale.

The observation of intra-group cognition showed better performance of the verbal IQ compared to the executive IQ. This is in agreement with the literature, which emphasizes the age-related decline in the performance of tasks which involve fluid intelligence, and preservation or improvement of those related to crystallized intelligence (Parente \& Wagner, 2006).

The fact that there was no statistical significance in the SF8-asessed cognitive performance between the age ranges of the G1 individuals may be accounted for by a sample bias, as this group was already cognitively impaired. With the exception of the Arithmetic subtest, no significant differences in the verbal performances were observed in the G2. This may be due to the persistence or crystallization of the verbal abilities with aging. The fact that the Arithmetic subtest assesses fluid intelligence and abstract reasoning may have added to the poorer performance seen among the elders (Parente \& Wagner, 2006).

In G2, significantly lower scores were observed for the executive IQ and PVI with older age. When the subtests making up the executive set were separately analyzed, there was a significant association between Digit-span coding and age range in this group. Once the referred subtest involves the speed and accuracy of the eye/hand coordination and short-term visual memory (Nascimento \& Figueiredo, 2002), reduced attention and working memory and slowing of information processing with aging may account for this worse performance (Salthouse, 2005). This finding underscores the importance of considering the age range in SF8-based cognitive assessment.

Gender difference did not interfere with cognitive performance, although there was an interesting finding: in the MRI subtests (Arithmetic and Digit span), men performed higher in both groups. Accordingly, the literature reports higher male performance in tasks involving logical and abstract reasoning (Haier, 2006).

Our results indicate that the SF8 is useful for the neuropsychological assessment of elders. Some limitations of this study were the use of a convenience sample and the lack of definition as to the cause of the cognitive impairment. Future studies should investigate the behavior of a representative sample of individuals with different diagnoses in the SF8.

\section{Conclusion}

Adequacy of the psychometric parameters, shorter application time, possibility of use under different contexts and great acceptability, all point to SF8 as an efficient instrument for the cognitive assessment of the elderly population. Its use by professionals of the neuropsychological field must thus be encouraged, for investigation, follow-up and differential diagnosis of cognitive impairment.

The use of recently published cut-off points for this SF (Banhato, Leite, Guedes, \& Chaoubah, 2010) may be a useful resource to identify cognitive impairment. Furthermore, it may afford a more rigorous diagnosis, as performance according to the different old age ranges is considered.

\section{References}

Alchieri, J. C., \& Cruz, R. M. (2003). Avaliação psicológica: Conceito, métodos e instrumentos. São Paulo, SP: Casa do Psicólogo.

Almeida-Filho, N., Santana, V. S., \& Pinho, A. R. (1984). Estudo epidemiológico dos transtornos mentais em uma população de idosos na área urbana de Salvador - BA. Jornal Brasileiro de Psiquiatria, 33, 114-120.

Andraca, I., Cobo, C., Rivera, F., \& Pizarro, F. (1993). Evaluación de la inteligencia através de formas cortas del WAIS para poblaciones de nivel socioeconómico bajo. Revista de Saúde Pública, 27, 334-339.

Argimon, I. I., \& Stein, L. M. (2005). Habilidades cognitivas em indivíduos muito idosos: Um estudo longitudinal. $\mathrm{Ca}$ dernos de Saúde Pública, 21, 64-72.

Banhato, E. F. C., Leite, I. C. G., Guedes, D. V., \& Chaoubah, A. (2010). Criterium validity of a Wechsler-III Scale Short Form in a Sample of Brazilian Elderly. Dementia \& Neuropsychologia, 4(3), 207-213.

Berquó, E. S., \& Leite, V. M. (1998). Algumas considerações sobre a demografia da população idosa no Brasil. Belo Horizonte, MG: Postgraduate.

Blay, S. L., Mari, J. J., \& Ramos, L. R. (1989). O uso do "Facehand Test" como instrumento para rastrear as síndromes psicorgânicas: Estudo piloto. Revista de Saúde Pública, 23, 395-400.

Brucki, S. M., Nitrini, R., Caramelli, P., Bertolucci, P. H., \& Okamoto, I. H. (2003). Sugestões para o uso do mini-exame do estado mental no Brasil. Arquivos de Neuro-Psiquiatria, 61, 777-781.

Cachioni, M. (2007). Programas de educação permaente e reintegração social: A experiência das Universidades da Terceira Idade. In O. V. Forlenza, Psiquiatria Geriátrica: Do diagnóstico precoce à reabilitação (pp. 391-398). São Paulo, SP: Atheneu.

Chaimowicz, F. (2007). O envelhecimento populacional no mundo. In O. V. Forlenza, Psiquiatria Geriátrica: Do diagnóstico precoce à reabilitação (pp. 11-15). São Paulo, SP: Atheneu.

Charchat-Fichman, H., Caramelli, P., Sameshima, K., \& Nitrini, R. (2005). Declínio da capacidade cognitiva durante o envelhecimento. Revista Brasileira de Psiquiatria, 27(12), 79-82.

Christensen, B. K., Girard, T. A., \& Bagby, R. M. (2007). Wechsler Adult Intelligence Scale-Third Edition short form for index and IQ scores in a psychiatric population. Psychological Assessment, 19, 236-240.

Coutinho, A. C. (2009). Investigação psicométrica de quatro formas abreviadas do WAIS-III para avaliação da inteligência. (Dissertação de Mestrado não-publicada). Universidade Federal de Minas Gerais, Belo Horizonte, MG.

Erbolato, R. M. (2002). Relações sociais na velhice. In E. V. Freitas, L. Py, A. L. Neri, F. A. X. Cançado, M. L. Gorzoni, \& S. M. Rocha (Eds.), Tratado de Geriatria e Gerontologia (pp. 383-393). Rio de Janeiro, RJ: Guanabara-Koogan. 
Folstein, M. F., Folstein, S. E., \& McHugh, P. R. (1975). "Minimental state". A practical method for grading the cognitive state of patients for the clinician. Journal of Psychiatric Research, 12, 189-198.

Haier, R. J. (2006). Teoria Biológica da Inteligência. In C. Flores-Mendoza \& R. Colom, Introdução à Psicologia das Diferenças Individuais (pp. 131-142). Porto Alegre, RS: Artmed.

Herrera, E., Jr., Caramelli, P., Silveira, A. S., \& Nitrini, R. (2002). Epidemiologic survey of dementia in a communitydwelling Brazilian population. Alzheimer Disease and Associated Disorders, 16, 103-108.

Instituto Brasileiro de Geografia e Estatística. (2002). Perfil dos idosos responsáveis pelos domicílios no Brasil, 2000. Estudo \& Pesquisa, 9, 20-24.

Instituto Brasileiro de Geografia e Estatística. (2010). Censo demográfico 2010. Retrieved December 10, 2010, from http:/ /www.ibge.gov.br/home/estatistica/populacao/censo2010/ default.shtm

Lopes, M. A. (2006). Estudo epidemiológico de prevalência de demência em Ribeirão Preto. (Tese de Doutorado nãopublicada). Universidade de São Paulo, SP.

Nascimento, E. (2004). WAIS-III: Escala de inteligência Wechsler para adultos. São Paulo, SP: Casa do Psicólogo.

Nascimento, E., \& Figueiredo, V. L. M. (2002). A terceira edição das Escalas Wechsler de Inteligência. In R. Primi (Ed.), Temas em avaliação psicológica (pp. 61-79). Campinas, SP: Impressão Digital do Brasil.

Neri, A. L. (2008). Palavras-chave em Gerontologia. Campinas, SP: Alínea.

Nitrini, R., Caramelli, P., Bottino, C. M., Damasceno, B. P., Brucki, S. M., \& Anghinah, R. (2005). Diagnóstico de doença de Alzheimer no Brasil: Avaliação cognitiva e funcional. Recomendações do Departamento Científico de Neurologia Cognitiva e do Envelhecimento da Academia Brasileira de Neurologia. Arquivos de Neuro-psiquiatria, 63(3A), 720-727.

Parente, M. A. M. P., \& Wagner, G. P. (2006). Teorias abrangentes sobre envelhecimento cognitivo. In M. A. M. P. Parente, Cognição e envelhecimento (pp. 31-45). Porto Alegre, RS: Artmed.

Salthouse, T. A. (2005). Relations between cognitive abilities and measures of executive functioning. Neuropsychology, 19, 532-545.

Stella, F. (2004). Funções cognitivas e envelhecimento. In L. Py, Tempo de envelhecer (pp. 283-320). Rio de Janeiro, RJ: Nau.

Wechsler, D. (1997). Wechsler adult intelligence Scale-III (3 $3^{\text {rd }}$ ed.). New York: Psychological Corporation.

Wymer, J. H., Rayls, K., \& Wagner, M. T. (2003). Utility of a clinically derived abbreviated form of the WAIS-III. Archives of Clinical Neuropsychology, 18(8), 917-927.

Xavier, F. M. (1999). Prevalência de declínio cognitivo assossiado ao envelhecimento em uma população de idosos com mais de 80 anos residentes na comunidade. (Dissertação de Mestrado não-publicada). Escola Paulista de Medicina, Universidade Federal de São Paulo, SP. 